\title{
Occurrence of flat bugs (Heteroptera: Aradidae) in burned and unburned forests
}

\author{
Joakim Hjältén, Ola Atlegrim, Frida Sandström, Roger Pettersson \& Eric A. Rexstad
}

Hjältén, J., Atlegrim, O., Sandström, F., Pettersson, R. \& Rexstad, E. A. 2006: Occurrence of flat bugs (Heteroptera: Aradidae) in burned and unburned forests. — Entomol. Fennica 17: 130-135.

The goal of this study was to determine the effect of fire on flat bug diversity and abundance in coniferous and mixed forests in interior Alaska. Eighty individuals, of which 78 in the burned areas and two in the control areas, of six aradid species were collected: Aradus abbas (Bergroth), A. funestus (Bergroth), A. lugubris (Fallén), A. signaticornis (Sahlberg), A. tuberculifer (Kirby) and Aneurus simplex (Uhler). Generally, all flat bug species were more abundant in the burned areas than in control areas with statistically significant differences for four of the six species and for pooled nymphs. Habitat preferences and potential mechanisms connecting mycophagy and pyrophagy are discussed.

J. Hjältén, O. Atlegrim, F. Sandström \& R. Pettersson, Department of Animal Ecology, Swedish University of Agricultural Sciences, 90183 Umeå, Sweden; Email: joakim.hjalten@szooek.slu.se

E. A. Rexstad, Institute of Arctic Biology, University of Alaska, Fairbanks, Alaska, U. S. A.

Received 6 May 2005, accepted 30 September 2005

\section{Introduction}

Human influences, such as fire suppression programs and modern forestry practise have led to changes in fire regimes in many boreal forests (Granström 2001). There are reports of a fire frequency of 60-100 years in the boreal forests of east-central Canada before European settlement, with a decrease to every 500-1,000 year after fire suppression began in the early $20^{\text {th }}$ century (McCullough et al. 1998). Similar pattern has been reported from the boreal forests of Fennoscandia (Granström 2001).

Changes in fire regimes have implications for ecosystem functioning, because fire disturbance is among the most important factors for maintaining diversity in the boreal forests (Zackrisson
1977, McLeod 1980, Esseen et al. 1997, Weber \& Stocks 1998). Fire disturbance "turns the clock back" i.e. creates early successional stages that are unfavorable to established and dominant species, but beneficial for less competitive and opportunistic or stress resistant species (Zackrisson 1977, Lyon et al. 1978, Esseen et al. 1997, Wikars 1997, 2001a, McCullough et al. 1998). The reduced fire frequency with the resulting dramatic decrease of dead wood availability in parts of North America, and more pronouncedly in Fennoscandian boreal forests, has led to remarkable decreases of many fire-associated organisms, and several species are today threatened and included in the national red lists (Gärdenfors 2000, Siitonen 2001, Wikars 2001b). However, in some areas, such as in the interior part of 
Alaska, fires are still frequent and large areas burn every year: on average 400,000 ha between 1940 and 1970, 240,000 ha during the 1970s and 370,000 ha during 1990-2001, which constitutes ca $0.9 \%, 0.6 \%$ and $0.8 \%$, respectively, of the total forested area in interior Alaska (Alaska Division of Forestry 2002). Haggstrom \& Kelleyhouse (1996) report that the logging in the boreal forest of interior Alaska has been relatively limited (400 ha annually) up to 1996 and the impacts of forestry have therefore been rather minor, but the local anthropogenic influence was strong at the beginning of the $20^{\text {th }}$ century during the gold rush.

In Alaska, one might therefore expect to find more intact and natural insect communities, still harbouring large populations of fire-favoured and pyrophilous species. Unfortunately, very few studies of the effects of fire on insect communities have been conducted in Alaska. Therefore, we have limited data pertaining to the importance of fire in maintaining insect diversity in these areas (McCullough et al. 1998). This study examines effects of fire on the abundance and diversity of Aradidae species in burned and non-burned areas in coniferous and mixed boreal forests in interior Alaska.

Aradidae (Heteroptera) are generally presumed to be mycophagous and some species are regarded as pyrophilous, but for many species detailed knowledge on their habitat requirements is lacking (Matsuda 1977, Heliövaara \& Väisänen 1983, Coulianos 1989, Wikars 1992). Pyrophilous insects often have a circumpolar distribution (Wikars 1997) and the information gained from this study has the potential to be applicable in boreal forests in other parts of the world.

\section{Methods}

\subsection{Study sites}

The burned sites were part of a prescribed fire covering 368 ha of the Caribou-Poker creek experimental research area $\left(65^{\circ} 10^{\prime} \mathrm{N}, 147^{\circ} 03^{\prime} \mathrm{W}\right)$, located $40 \mathrm{~km}$ northeast of Fairbanks, Alaska. In the north-facing research area used in this study there was an altitudinal gradient of tree species with black spruce (Picea mariana Mill. B. S. P) on ridge tops, trembling aspen (Populus tremu- loides Michx.) and paper birch (Betula papyrifera Marsh.) in valleys, and mixed forest in between (C. L. Fastie, A. Lloyd, H. Doak \& P. Doak unpubl.).

In the study area there had been five large fires during the last 200 years. These took place between 1896 and 1925 but there is no part of the area that has been burned by more than one severe fire during the last 200 years (C. L. Fastie, A. Lloyd, H. Doak \& P. Doak unpubl.).

\subsection{Study organisms}

There are 49 Aradus species and three Aneurus species known to occur in Canada and adjacent states of the USA and ten Aradus species and two Aneurus species occur in Alaska (Matsuda 1977, Maw et al. 2000). In comparison, 17 Aradus and one Aneurus species have been found in Finland and 20 Aradus and one Aneurus in Sweden (Heliövaara \& Väisänen 1983, Coulianos 1989). The flat bugs are generally forest insects and, in temperate and boreal forests, commonly occur under the bark of dead or burnt trees or on polypore fungi (Usinger 1936, Matsuda 1977, Heliövaara \& Väisänen 1983, Froeschner 1988, Taylor 1988, Wikars 1992, Deyrup \& Mosley 2004). They occur on both coniferous and deciduous trees. All flat bugs, except for Aradus cinnamomeus (Europe), A. kormilevi, and A. antennalis (North America), are regarded as mycophagous (Usinger 1936, Matsuda 1977, Froeschner 1988, Taylor 1988). Some aradids prefer burned wood, presumably feeding on fungal hyphae and/or spores living in these special environments (Heliövaara \& Väisänen 1983, Coulianos 1989, Wikars 1992).

\subsection{Sampling}

After the prescribed fire (8-15 July 1999), insects were collected using window traps during three periods: (1) placed 30-32 July, retrieved $27 \mathrm{Au}-$ gust 1999; (2) placed 10 June, retrieved 17 July 2000; and (3) placed 17 July, retrieved 21 August 2000. We used window traps, standing on the ground between two trees. They consisted of vertical Plexiglas plates $(40 \mathrm{~cm} \times 60 \mathrm{~cm})$ with alu- 
Table 1. The species found, with number of individuals collected in parentheses $(n)$. The table shows mean number of individuals / trap * 100 days found in burned areas (BRN) and in unburned control (CTR) areas during the periods A (30-31 July to 27 August 1999), B (10 June to 17 July 2000) and C (17 July to 21 August 2000), mean values for all periods, and $p$ values for differences between burned and control areas ( $N / A=$ not analyzed).

\begin{tabular}{|c|c|c|c|c|c|c|c|c|c|}
\hline \multirow[t]{2}{*}{ Species $(n)$} & \multicolumn{2}{|c|}{ Period A } & \multicolumn{2}{|c|}{ Period B } & \multicolumn{2}{|c|}{ Period C } & \multicolumn{2}{|c|}{ Mean of all } & \multirow{2}{*}{$\frac{U \text {-test }}{p}$} \\
\hline & BRN & CTR & BRN & CTR & BRN & CTR & BRN & CTR & \\
\hline Aradus abbas (16) & 3.26 & 0 & 0.63 & 0 & 0.19 & 0 & 1.12 & 0 & 0.0219 \\
\hline A. funestus (21) & 3.26 & 0 & 0 & 0 & 0 & 0 & 0.92 & 0 & 0.0071 \\
\hline A. lugubris (29) & 7.07 & 0 & 1.68 & 0.15 & 0.59 & 0 & 2.79 & 0.05 & 0.0132 \\
\hline A. signaticornis (6) & 0 & 0 & 1.05 & 0.15 & 0 & 0 & 0.35 & 0.05 & 0.1530 \\
\hline A. tuberculifer (5) & 0 & 0 & 0.63 & 0 & 0.39 & 0 & 0.34 & 0 & 0.0585 \\
\hline Aneurus simplex (3) & 0 & 0 & 0.63 & 0 & 0 & 0 & 0.25 & 0 & N/A \\
\hline Nymphs (24) & 0 & 0 & 3.16 & 0 & 1.77 & 0 & 1.58 & 0 & 0.0021 \\
\hline
\end{tabular}

minium trays beneath on both sides, and contained propylene glycol and a small amount of detergent.

We used six trapping areas (200-500 m apart) along an altitudinal trap line following the fire front in the upper part of the slope dominated by spruce and mixed forest. Each trap area consisted of two trap stations $(20 \mathrm{~m} \times 20 \mathrm{~m}$, each with three window traps), one situated $50-100 \mathrm{~m}$ into the burned area and one 50-100 $\mathrm{m}$ into the surrounding unburned forest.

The flat bugs were identified using Matsuda (1977) but the nomenclature follows Maw et al. (2000). Our identifications were verified by C.-C. Coulianos. The nymphs were not determined to species. Five out of 36 of the traps in each sampling period (but not the same traps), were not fully functional due to turned over vessels or laying windows. We adjusted the data for missing traps and differences in the length of the trapping periods by presenting data as mean numbers of individuals/trap/100 trap days.

\subsection{Statistical analyses}

Due to a limited sample size we pooled the data from different years and only evaluated the overall effect of fire on the abundance of species for which more than five individuals were trapped. For this purpose, we used Mann-Whitney $U$-test.

\section{Results}

Eighty individuals belonging to six aradid species were collected: Aradus abbas Bergroth, A. funestus Bergroth, A. lugubris Fallén, A. signaticornis Sahlberg, A tuberculifer Kirby and Aneurus simplex Uhler. Nymphs were also trapped (24 individuals), but these were pooled in the analyses (Table 1). More aradid species and individuals were found in burned areas. In fact, only two adult individuals were found in the control areas: one A. lugubris and one A. signaticornis, both during 2000. The differences in abundances between areas were statistically significant for four of the five species tested: $A$. abbas, A. funestus, $A$. lugubris and $A$. tuberculifer (marginally significant), as well as for nymphs (Table 1 ).

\section{Discussion}

Generally, all Aradus and Aneurus species found occurred most frequently in burned areas, but due to the low sample size, this could only be verified statistically for four of the six species and for nymphs. Several characteristics of burned areas can favour insects, e.g. an increased amount of dead wood and breeding material, reduced competition, more easily attainable nutrients and changed microclimate, e.g. decreased humidity and increased sun radiation (Wikars 1992, 1997, Esseen et al. 1997). Additionally, studies from Fennoscandia have revealed that many species of 
fungi, including ascomycetes such as Daldinia species, become more abundant in burned forest (Wikars 1992, Johannesson 2000), and because all Aradus species except $A$. cinnamomeus, $A$. kormilevi and $A$. antennalis are regarded as mycophagous (Usinger 1936, Matsuda 1977, Taylor 1988), this is probably the main reason for their preference for burned areas.

Few earlier studies have investigated the effect of fire on flat bugs. However, A. lugubris has previously been reported to prefer burned areas both in Fennoscandia (Heliövaara \& Väisänen 1983, Coulianos 1989, Wikars 1992, 1997, Lappalainen \& Simola 1998) and in North America (Bess et al. 2002). Long distance dispersal, an important characteristic for pyrophilous species, is known for A. lugubris, and individuals have been found far from their present continuous distribution area (Coulianos 1989). Also supporting fire dependence is the fact that A. lugubris is known to utilize Daldinia loculata, a fire dependent, wood living ascomycete in Sweden (Wikars 2001a). It is likely that $A$. lugubris has similar substrate preferences in Alaska as in Scandinavia because $D$. loculata has a circumpolar distribution (Wikars 2001b) and Daldinia species is common on burned birches in the burned area in this study (J. Hjältén pers. obs.). However, Matsuda (1977) and Heliövaara \& Väisänen (1983) report that A. lugubris is associated with Pinus ponderosa, Pinus sylvestris, Picea engelmanni, Picea excelsa and Juniperus communis, with a remark that A. lugubris prefers burned pine forests.

Aradus funestus, the second most common species, only occurred in burned areas. Associations with Pseudotsuga taxifolia and Abies concolor (Matsuda 1977), and Abies lasiocarpa and Picea glauca (Scudder 1997) have been reported for this species. Two individuals of $A$. funestus were caught on black spruce with emergence eclector traps at the research site in 2002 (J. Hjältén unpubl.), suggesting that black spruce is used as a host. Also Aradus tuberculifer exclusively occurred in burned areas, and the sparse information available indicates that this species also might prefer spruce forest, because it is closely related to A. funestus (Matsuda 1977). Both A. abbas and Aneurus simplex only occurred in burned areas, and the limited biological information available suggests that the former species is widely distributed in North America and associated with Pinus ponderosa, Pinus sylvestris and Taxodium species.

A. signaticornis had slightly albeit statistically non-significantly higher abundance in burned areas, and it has earlier been reported to prefer burned forests. Coulianos (1989), Heliövaara \& Väisänen (1983) and Gärdenfors (2000) report that the rare $A$. signaticornis has been found mainly on burned trees in Fennoscandia. Long distance dispersal is known also from this species (Coulianos 1989), and larvae feed on wood living ascomycetes (Wikars 1997) that are more common in burned forests (Wikars 2001a, 2001b). This indicates that $A$. signaticornis is probably favoured by fire, but that our sample size was too small to verify this.

Our results indicate that several flat bug species might be favoured by fire and that fire is probably important for maintaining viable populations of these insects. Many species seem to be sensitive to intensive forestry and fire suppression. For example, two of the 17 Aradus species found in Finland have disappeared since the $19^{\text {th }}$ century, and seven more, including the endangered A. signaticornis is on the Finnish Red list (Rassi et al. 2001). Siitonen and Martikainen (1994) compared the occurrence of rare beetles and flat bugs in Finnish Karelia with that of Russian Karelia, where the forest management has been much less intensive. Twenty-one rare insect species were found in Russian Karelia, compared to only five in Finnish Karelia. Three Aradus species was found in Karelia, of which A. truncatus is threatened (vulnerable), A. crenaticollis was considered threatened at the time of the study but is no longer considered as a red-listed species in Finland (Rassi et al. 2001), and A. ribauti that has not been found in Finland (Rassi et al. 2001). Moreover, eight of the 21 Swedish Aradus species, including $A$. signaticornis, and one Aneurus species are red-listed in Sweden (Coulianos 1989, Gärdenfors 2000). The occurrence of flat bugs such as $A$. signaticornis in our Alaskan site probably indicates a low level of anthropogenic influence in this forest ecosystem and a high frequency of fires. By contrast, the disappearance of many flat bugs in Fennoscandia is probably a result of intensive forest management in combination with fire suppression programs that have 
practically eliminated forest fires in Fennoscandia (Granström 2001). However, it should be noted that there is increasing evidence that many saproxylic species are favoured by the rich pulse of dead wood following the fire rather than the fire itself(Wikars 2001), which may indicate that forest harvesting with substantial amounts of retained wood could sustain at least a proportion of the rare saproxylic species.

Increasing awareness of the role of fire as an ecological factor in the forests has led to the introduction of prescribed burning to imitate the effects of natural fires in the management of some nature reserves in Fennoscandia, and in national parks in Canada and Alaska (Wikars 1992, Haggstrom \& Kelleyhouse 1996, Lappalainen \& Simola 1998, Weber \& Stocks 1998). Increasing evidence suggests that this is probably a good strategy and that prescribed burning should be used as a management strategy in managed forests also (Hyvärinen et al. 2005). However, we still lack basic knowledge on habitat requirement for many species, e.g. on the association with specific wood fungi, which makes it difficult to give solid recommendations regarding management strategies. Gaining basic knowledge on habitat requirements and nutritional ecology for threatened insect species should therefore be given high priority.

Acknowledgements. We thank A. Constantinides and C.-C. Coulianos for help with the flat bug identification and S. Chapin for giving us permission to use the Frostfire site. The study was financed by STINT.

\section{References}

Alaska Division of Forestry 2002: Fire Statistics. Alaska Department of Natural Resources, http:// www.dnr.state.ak.us/forestry/firestats.htm (Access date April 18, 2002).

Bess, E. C., Parmenter, R. R., McCoy, S. \& Molles M. C. M. Jr. 2002: Responses of a riparian forest-floor arthropod community to wildfire in the middle Rio Grande Valley, New Mexico. — Environmental Entomology 31: 774-784.

Coulianos, C. C. 1989: Nya landskapsfynd av barkstinkflyn (Hem.- Het., Aradidae) jämte Aradus truncatus, ny för Sverige. [New provincial records of Swedish flat bugs (Hem.- Het., Aradidae) with Aradus truncatus, new record to Sweden]. — Entomol. Tidskr. 110: 53-57. [In Swedish.]
Deyrup, M. \& Mosley, J. G. 2004: Natural History of the flat bug Aradus gracilicornis in fire killed pines (Heteroptera: Aradidae). — Florida Entomologist 87: 79_ 81.

Esseen, P.-A., Ehnström, B., Ericsson, L. \& Sjöberg, K. 1997: Boreal forests. - Ecological Bulletins 46: 1647.

Froeschner, R. C. 1988: Family Aradidae Spinola, 1837, The Flat Bugs. - In: Henry, T. J. \& Froeschner, R. C. (eds.), Catalogue of the Heteroptera, or True bugs, of Canada and the Continental US. E. J. Brill, USA.

Granström, A. 2001: Fire management for biodiversity in the European boreal forest. - Scandinavian Journal of Forest Research Suppl. 3: 62-69.

Gärdenfors, U. (ed.) 2000: Rödlistade arter i Sverige 2000. [The 2000 Red List of Swedish species.] ArtDatabanken, SLU, Uppsala. [In Swedish. ]

Haggstrom, D.A. \& Kelleyhouse, D.G. 1996: Silviculture and wildlife relationships in the boreal forest of interior Alaska. - Forestry Chronicle 72 (1):59-62.

Heliövaara, K. \& Väisänen, R. 1983: Environmental changes and the flatbugs (Heteroptera, Aradidae and Aneuridae). Distribution and abundance in eastern Fennoscandia. - Annales Entomologici Fennici 49: 103-109.

Hyvärinen, E., Kouki, J, Martikainen, P. \& Lappalainen, H. 2005: Short-term effects of controlled burning and green-tree retention on beetle assemblages in managed boreal forests. - Forest Ecology and Management 212: $315-332$

Johannesson, H. 2000: Ecology of Daldinia spp. with special emphasis on Daldinia loculata. - PhD thesis, Swedish University of Agricultural Sciences, Uppsala. Silvestria 168.

Lappalainen, H. \& Simola, H. 1998: The fire-adapted flatbug Aradus laeviusculus Reuter (Heteroptera, Aradidae) rediscovered in Finland (North Karelia, Koli National Park). — Entomologica Fennica 9: 3-4.

Lyon, L. J., Crawford, H. S., Czuhai, E., Fredriksen, R. L., Harlow, R. F., Metz, L. J. \& Pearson, H. A. 1978: Effects of Fire on Fauna. — Gen. Tech. Rep.WO-6. U. S. Department of Agriculture, Forest Service. 22 pp.

Matsuda, R. 1977: The Insects and Arachnids of Canada. Part 3. The Aradidae of Canada. Hemiptera: Aradidae. - Biosystematics Research Institute, Ottawa, Ontario Research branch Canada. Department of Agriculture.

Maw, H. E. L., Footit, R. G., Hamilton, K. G. A. \& Scudder, G. G. E. 2000: Checklist of the hemiptera of Canada and Alaska. - NRC Research Press, Ottawa.

McCullough, D. G., Werner, R. A. \& Neuman, D. 1998: Fire and insects in northern and boreal forest ecosystems of North America. - Annual Review of Entomology 43: 107-127.

McLeod, J. M. 1980: Forests, Disturbances, and Insects. — Canadian Entomologist 112: 1185-1192.

Rassi, P., Alanen, A., Kanerva, T. \& Mannerkoski, I. (eds.). 2001. The Red List of Finnish Species. - Ministry of the Environment \& Finnish Environment Institute, Helsinki. 432 pp. [In Finnish with English summary.]

Scudder, G. G. E. 1997: True bugs (Heteroptera) of the Yu- 
kon. - In: Danks, H. V. \& Downes, J. A. (eds.), Insects of the Yukon: 241-336. Biological Survey of Canada (Terrestrial Arthropods), Ottawa.

Siitonen, J. 2001: Forest management, coarse woody debris and saproxylic organisms: Fennoscandian boreal forest as an example. — Ecological Bulletins 49: 1141.

Siitonen, J. \& Martikainen, P. 1994: Occurrence of rare and threatened insects living on decaying Populus tremula: a comparison between Finnish and Russian Karelia. - Scandinavian Journal of Forest Research 9: 185-191.

Taylor, S. J. 1988: Observations on parental care in the family Aradidae (Heteroptera). - The Great Lakes Entomologist Vol. 21, No. 4.

Usinger, R. L. 1936: Studies in the American Aradidae with descriptions of new species (Hemiptera). - Annals of the Entomological Society of America 29(3): 490-516.
Weber, M. G. \& Stocks, B. J. 1998: Forest fires and sustainability in the boreal forest of Canada. - Ambio 27: 545-550.

Wikars, L.-O. 1992: Skogsbränder och insekter. [Forest fires and insects]. — Entomologisk Tidskrift 113 (4): 1-11. [In Swedish.]

Wikars, L.-O. 1997: Effects of forest fire and the ecology of fire-adapted insects. - PhD-thesis Faculty of Science and Technology, Uppsala University.

Wikars, L.-O. 2001a: The wood-decaying fungus Daldinia loculata (Xylariaceae) as an indicator of fire-dependent insects. - Ecological Bulletins 49: 263-268.

Wikars, L.-O. 2001b: Dependence on fire in wood-living insects: An experiment with burned and unburned spruce and birch logs. - Journal of Insect Conservation 6: 1-12.

Zackrisson, O. 1977: Influence of forest fires on the North Swedish boreal forest. — Oikos 29: 22-32. 